\title{
Amino Acids, Glutamine, and Protein Metabolism in Very Low Birth Weight Infants
}

\author{
PRABHU S. PARIMI, MARK M. KADROFSKE, LOURDES L. GRUCA, RICHARD W. HANSON, \\ AND SATISH C. KALHAN \\ Department of Pediatrics, Schwartz, Center for Metabolism and Nutrition, Case Western Reserve \\ University School of Medicine, MetroHealth Medical Center, Cleveland, Ohio, 44109
}

\section{ABSTRACT}

\begin{abstract}
Glutamine has been proposed to be conditionally essential for premature infants, and the currently used parenteral nutrient mixtures do not contain glutamine. De novo glutamine synthesis (DGln) is linked to inflow of carbon into and out of the tricarboxylic acid (TCA) cycle. We hypothesized that a higher supply of parenteral amino acids by increasing the influx of amino acid carbon into the TCA cycle will enhance the rate of DGln. Very low birth weight infants were randomized to receive parenteral amino acids either $1.5 \mathrm{~g} / \mathrm{kg} / \mathrm{d}$ for $20 \mathrm{~h}$ followed by $3.0 \mathrm{~g} / \mathrm{kg} / \mathrm{d}$ for $5 \mathrm{~h}$ (AA1.5) or $3.0 \mathrm{~g} / \mathrm{kg} / \mathrm{d}$ for $20 \mathrm{~h}$ followed by $1.5 \mathrm{~g} / \mathrm{kg} / \mathrm{d}$ for $5 \mathrm{~h}$ (AA3.0). A third group of babies received amino acids $1.5 \mathrm{~g} / \mathrm{kg} / \mathrm{d}$ for $20 \mathrm{~h}$ followed by $3.0 \mathrm{~g} / \mathrm{kg} / \mathrm{d}$ for $20 \mathrm{~h}$ (AA-Ext). Glutamine and protein/nitrogen kinetics were examined using $\left[5-{ }^{15} \mathrm{~N}\right]$ glutamine, $\left[{ }^{2} \mathrm{H}_{5}\right]$ phenylalanine, $\left[1-{ }^{13} \mathrm{C},{ }^{15} \mathrm{~N}\right]$ leucine, and $\left[{ }^{15} \mathrm{~N}_{2}\right]$ urea tracers. An acute increase in parenteral amino acid infusion for
\end{abstract}

$5 \mathrm{~h}$ (AA1.5) resulted in decrease in rate of appearance ( $\mathrm{Ra}$ ) of phenylalanine and urea, but had no effect on glutamine Ra. Infusion of amino acids at $3.0 \mathrm{~g} / \mathrm{kg} / \mathrm{d}$ for $20 \mathrm{~h}$ resulted in increase in DGln, leucine transamination, and urea synthesis, but had no effect on Ra phenylalanine (AA-Ext). These data show an acute increase in parenteral amino acid-suppressed proteolysis, however, such an effect was not seen when amino acids were infused for $20 \mathrm{~h}$ and resulted in an increase in glutamine synthesis. (Pediatr Res 58: 1259-1264, 2005)

\section{Abbreviations}

BGIn, glutamine derived from proteolysis

DGIn, de novo glutamine synthesis

TCA, tricarboxylic acid

VLBW, very low birth weight
Glutamine participates in a number of key metabolic processes (1) and is also proposed to play an important role in enhancing immune function (2-4). A decrease in plasma glutamine concentration in response to stress (acute illness, burns, trauma, etc.) suggests that the rate of DGln is unable to keep pace with the rate of utilization/requirement. This has led several investigators to suggest that glutamine is a conditionally essential amino acid. Studies in adults show that parenteral nutrition supplemented with glutamine decreased both the morbidity and mortality $(5,6)$.

Because the concentration of plasma glutamine is lower in VLBW infants, and the currently used parenteral nutrient solutions do not contain glutamine, VLBW premature infants were identified as another group of subjects who could potentially benefit from supplementation of enteral and parenteral nutrition with glutamine (7-9). However, whether provision of

Received February 15, 2005; accepted May 10, 2005.

Correspondence: Prabhu S. Parimi, M.D., Schwartz Center for Metabolism and Nutrition, G 735, MetroHealth Medical Center, 2500 MetroHealth Dr., Cleveland, OH 44109; e-mail: pparimi@metrohealth.org

This work was supported by National Institutes of Health grant RO1 HD042154 and General Clinical Research Center grant RR00080.

DOI: 10.1203/01.pdr.0000185130.90205.1f a higher amount of parenteral amino acids to these VLBW infants enhances the rate of DGln has not been examined.

Glutamine is synthesized by transamination of $\alpha$-ketoglutarate to glutamate and conversion of glutamate to glutamine. The latter reaction is catalyzed by glutamine synthase. The sources of carbon skeleton for the synthesis of glutamine, i.e. glutamate and $\alpha$-ketoglutarate, are derived from the amino acids entering the TCA cycle (anaplerosis). An increase influx of these amino acids would be anticipated to result in an increase in DGln (cataplerosis) (10). Studies in human adults show that supplementation of parenteral nutrition with analogues of $\alpha$-ketoglutarate enhances the intracellular pool of glutamine in the muscle $(11,12)$. We have previously shown that the rate of appearance of glutamine in newborn infants is positively correlated with whole body rate of protein breakdown (13), suggesting that an increased availability of amino acids augments DGln. We hypothesized that supply of a higher amount of parenteral amino acids to clinically stable VLBW infants will increase the anaplerotic flux of carbon into the TCA cycle, increase transamination, and accelerate the rate of DGln. We have tested the hypothesis by examining the effect of parenteral amino acids, either $1.5 \mathrm{~g} / \mathrm{kg} / \mathrm{d}$ or $3 \mathrm{~g} / \mathrm{kg} / \mathrm{d}$ for either $5 \mathrm{~h}$ or $20 \mathrm{~h}$, on glutamine, phenylalanine, leucine nitro- 
gen, and urea kinetics in premature infants $\leq 32$ wk gestation and $\leq 1500 \mathrm{~g}$ birth weight using a randomized study design.

\section{METHODS}

Subjects. Preterm infants $\leq 32 \mathrm{wk}$ gestation and $\leq 1500 \mathrm{~g}$ were recruited. After verbal assent from their primary physician, written informed consent was obtained from the parent(s), after fully explaining the procedures. The study protocol was approved by the Institutional Review Board. All studies were performed in the neonatal intensive care unit at MetroHealth Medical Center.

Premature infants were randomized to receive an initial parenteral nutrition containing either $1.5 \mathrm{~g} / \mathrm{kg} / \mathrm{d}(\mathrm{AA} 1.5, n=12)$ or $3 \mathrm{~g} / \mathrm{kg} / \mathrm{d}$ (AA3.0, $n=12)$ of amino acids (10\% TrophAmine, McGaw, Irvine, CA). After $16 \mathrm{~h}$ of amino acid infusion, kinetic studies were performed as described below. Thereafter, the amino acid load was increased to $3 \mathrm{~g} / \mathrm{kg} / \mathrm{d}$ in AA1.5 group and decreased to 1.5 $\mathrm{g} / \mathrm{kg} / \mathrm{d}$ in AA3.0 group and infused for the next $5 \mathrm{~h}$, while the infants continued to receive isotopic tracer infusion. Because the second part of the study in AA1.5 and AA3.0 groups was only $5 \mathrm{~h}$ as compared with $20 \mathrm{~h}$ in the first part, a third group (AA-Ext) was also studied where the tracer studies were performed after $20 \mathrm{~h}$ of amino acid infusion at $1.5 \mathrm{~g} / \mathrm{kg} / \mathrm{d}$ and at $3.0 \mathrm{~g} / \mathrm{kg} / \mathrm{d}$ (Fig. 1). Clinical characteristics of the infants and the acuity of illness at birth, assessed by Scoring of Neonatal Acute Physiology (SNAP), were not different between the study subjects (Table 1). Tracer isotope studies were performed at a mean age of $5 \pm 1 \mathrm{~d}$. Infants were on either minimal ventilator support (defined by Fio ${ }_{2} \leq 35 \%$ and mean air way pressure $\leq 8$ ) (AA1.5, $n=5$; AA 3.0, $n=5$, AA-Ext, $n=2$ ), or were receiving supplemental oxygen via nasal canula. None of the infants were on insulin or vasopressor support or were receiving corticosteroids. All babies were placed on antibiotics immediately after birth for presumed infection, as per the clinical practice at our institution. None of the study infants had bacteriologically proven sepsis. Their primary neonatologist was responsible for all the clinical care including necessary adjustments in intravenous fluids, initiation of parenteral nutrition, and enteral feeding. None of the infants were receiving enteral feeds at the time of tracer study. Generally, babies received $10 \%$ dextrose water during the first $24 \mathrm{~h}$ after birth and were started on parenteral amino acids between 24 and $72 \mathrm{~h}$ of age.

During the $24 \mathrm{~h}$ before the study, infants were receiving energy $56 \mathrm{kcal} / \mathrm{kg} / \mathrm{d}$, glucose $8 \mathrm{mg} / \mathrm{kg} / \mathrm{min}$ and amino acids $1.6 \mathrm{~g} / \mathrm{kg} / \mathrm{d}$. Similarly, parenteral energy and glucose load were not different between the groups (Table 2).

Tracer infusions. After $16 \mathrm{~h}$ of prescribed parenteral amino acids, isotopic tracers were administered using the preexisting indwelling intravenous catheters. The tracer infusion was piggy-backed to the parenteral amino acid solution and continued for $9 \mathrm{~h}$ (AA1.5 and AA3.0) and for $4 \mathrm{~h}$ in the AA-Ext group (Fig. 1). The tracer solution was infused at $3 \mathrm{~mL} / \mathrm{h}$. L- $\left[5^{-15} \mathrm{~N}\right]$ glutamine $\left(99\right.$ atom $\%{ }^{15} \mathrm{~N}$ ) was obtained from Cambridge Isotopes Laboratories (An-
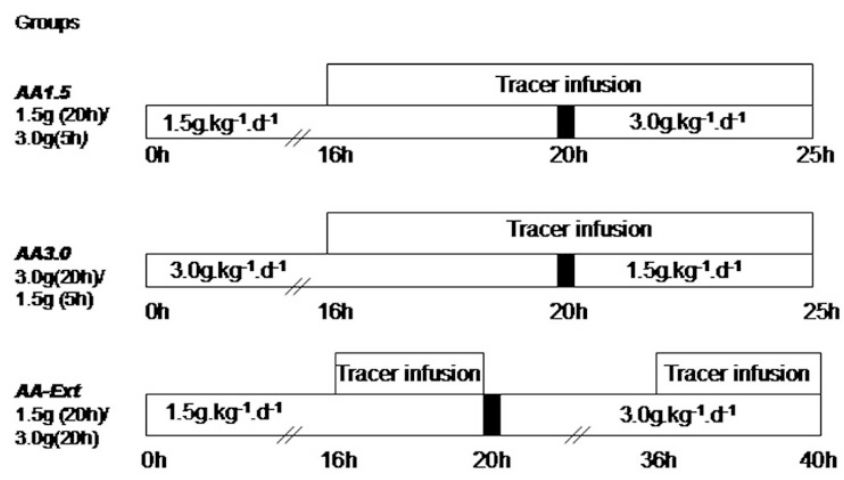

Figure 1. A prime constant rate infusion of tracer amino acids and urea was started $16 \mathrm{~h}$ after initiation of either $1.5 \mathrm{~g} / \mathrm{kg} / \mathrm{d}$ (AA1.5) or $3 \mathrm{~g} / \mathrm{kg} / \mathrm{d}$ (AA3.0) of parenteral amino acids. Blood samples were obtained before the start of tracer amino acid infusion and again between 210 and $240 \mathrm{~min}$ to measure the dilution of the tracers. Thereafter, the amount of parenteral amino acid solution was changed to $3 \mathrm{~g} / \mathrm{kg} / \mathrm{d}$ in AA1.5 group and $1.5 \mathrm{~g} / \mathrm{kg} / \mathrm{d}$ in AA3.0 group, and another set of blood samples were obtained between 510 and $540 \mathrm{~min}$. In the third group (AA-Ext), $16 \mathrm{~h}$ after infusion of $1.5 \mathrm{~g} / \mathrm{kg} / \mathrm{d}$ of parenteral amino acids, tracer amino acids and urea were infused for $4 \mathrm{~h}$ and blood samples were obtained between 210 and $240 \mathrm{~min}$. Thereafter, tracer amino acid solution was discontinued, and parenteral amino acid infusion was changed to $3 \mathrm{~g} / \mathrm{kg} / \mathrm{d}$ and infused for the next $16 \mathrm{~h}$. The tracer study was repeated the following day as described above.
Table 1. Clinical characteristics

\begin{tabular}{|c|c|c|c|c|c|c|}
\hline & $\begin{array}{c}\text { Birth } \\
\text { weight (g) }\end{array}$ & $\begin{array}{l}\text { Gestational } \\
\text { age (wk) }\end{array}$ & $\begin{array}{l}\text { Age } \\
\text { (d) }\end{array}$ & $\mathrm{M} / \mathrm{F}$ & $\begin{array}{l}\text { Weight at } \\
\text { study }(\mathrm{g})\end{array}$ & SNAP \\
\hline $\begin{array}{l}\text { AA } 1.5 \\
\quad(n=12)\end{array}$ & $1139 \pm 276$ & $29 \pm 2$ & $5 \pm 1$ & $6 / 6$ & $1009 \pm 270$ & $12(5-18)^{*}$ \\
\hline $\begin{array}{l}\text { AA } 3.0 \\
\quad(n=12)\end{array}$ & $1189 \pm 324$ & $28 \pm 2$ & $5 \pm 1$ & $8 / 4$ & $1093 \pm 308$ & $12(7-20)$ \\
\hline $\begin{array}{l}\text { AA-Ext } \\
\quad(n=5)\end{array}$ & $1132 \pm 289$ & $28 \pm 2$ & $4 \pm 1$ & $0 / 5$ & $1035 \pm 263$ & $13(9-21)$ \\
\hline
\end{tabular}

AA1.5: Parenteral amino acids $1.5 \mathrm{~g} / \mathrm{kg} / \mathrm{d}$ for $20 \mathrm{~h}, 3 \mathrm{~g} / \mathrm{kg} / \mathrm{d}$ for $5 \mathrm{~h}$. AA3.0: Parenteral amino acids $3 \mathrm{~g} / \mathrm{kg} / \mathrm{d}$ for $20 \mathrm{~h}, 1.5 \mathrm{~g} / \mathrm{kg} / \mathrm{d}$ for $5 \mathrm{~h}$. AA-Ext: Parenteral amino acids $1.5 \mathrm{~g} / \mathrm{kg} / \mathrm{d}$ for $20 \mathrm{~h}, 3 \mathrm{~g} / \mathrm{kg} / \mathrm{d}$ for $20 \mathrm{~h}$.

Data shown are mean \pm SD. *Median (25-75\%). No significant difference between the groups.

dover, MA). L- $\left[{ }^{2} \mathrm{H}_{5}\right]$ phenylalanine (98 atom $\%{ }^{2} \mathrm{H}$ ), $\left[{ }^{15} \mathrm{~N}_{2}\right]$ urea (98 atom \% $\left.{ }^{15} \mathrm{~N}\right)$ and $\mathrm{L}-\left[{ }^{13} \mathrm{C},{ }^{15} \mathrm{~N}\right]$ leucine $\left(98 \%{ }^{13} \mathrm{C}\right.$ and $\left.98 \%{ }^{15} \mathrm{~N}\right)$ were purchased from Merck \& Co. (Dorvall, Canada). Each batch of the tracers was tested for sterility and pyrogenicity as previously described (14). The administered doses of various tracers were as follows: L- $\left[5-{ }^{15} \mathrm{~N}\right]$ glutamine (prime, $30 \mu \mathrm{mol} / \mathrm{kg}$; constant rate $30 \mu \mathrm{mol} / \mathrm{kg} / \mathrm{h}, \mathrm{L}-\left[{ }^{2} \mathrm{H}_{5}\right]$ phenylalanine (prime, $6 \mu \mathrm{mol} / \mathrm{kg}$; constant rate, $4 \mu \mathrm{mol} / \mathrm{kg} / \mathrm{h}$ ), $\left.{ }^{15} \mathrm{~N}_{2}\right]$ urea (prime, $33 \mu \mathrm{mol} / \mathrm{kg}$; constant rate, $3.3 \mu \mathrm{mol} /$ $\mathrm{kg} / \mathrm{h}$ ) and $1-\left[{ }^{13} \mathrm{C},{ }^{15} \mathrm{~N}\right]$ leucine (prime, $7.5 \mu \mathrm{mol} / \mathrm{kg}$; constant rate, $7.5 \mu \mathrm{mol} /$ $\mathrm{kg} / \mathrm{h})$. Blood samples ( $\sim 0.7 \mathrm{~mL}$ each depending upon the baby's weight) were obtained before beginning the tracer infusion and again at 15 -min intervals between 210 and $240 \mathrm{~min}$. At $240 \mathrm{~min}$, following the last blood sample, the parenteral amino acids solution was changed as described. Another set of blood samples were collected between 510 and $540 \mathrm{~min}$.

In the AA-Ext group, tracer infusion was begun $16 \mathrm{~h}$ after parenteral nutrition at $1.5 \mathrm{~g} / \mathrm{kg} / \mathrm{d}$ and continued for $4 \mathrm{~h}$. Blood samples were obtained between 210 and $240 \mathrm{~min}$, after which the tracer infusion was discontinued, and the dose of parenteral amino acid was increased to $3.0 \mathrm{~g} / \mathrm{kg} / \mathrm{d}$. Tracer isotope study was repeated after $16 \mathrm{~h}$ of parenteral amino acid infusion at 3.0 g/kg/d (Fig. 1).

Heparinized plasma samples were deproteinized using $10 \%$ trichloroacetic acid and stored at $-70^{\circ} \mathrm{C}$ for later analysis. The rate of infusion of tracers was confirmed gravimetrically at the end of the study using the same tubing and infusion pump.

Analytical procedures. Laboratory analyses were performed on all infants unless indicated in "Results." All the analytical procedures used have been previously described from this laboratory (15-21). Plasma insulin was measured (Linco Research, St. Charles, MO) to examine its response to different amounts of amino acid. C-Reactive protein (CRP; ACTIVE US C-Reactive Protein ELISA assay kit; Diagnostic Systems Laboratories, Webster, TX), plasma cortisol $(n=12)$ (Coat-A-Count, DPC, Los Angeles, CA), and tumor necrosis factor (TNF)- $\alpha(n=4)$ (Bio-Rad, Hercules, CA) were measured to evaluate the degree of stress.

Calculations. The rate of appearance of glutamine, phenylalanine, leucine nitrogen, and urea in the plasma were calculated using tracer dilution equation: $\mathrm{Ra}(\mu \mathrm{mol} / \mathrm{kg} / \mathrm{h})=\mathrm{I} \times[(\mathrm{Ei} / \mathrm{Ep})-1]$, where $\mathrm{Ra}$ is the rate of appearance of the substrate, $\mathrm{I}$ is the rate of infusion of the tracer isotope, Ei is the tracer enrichment of the infusate, and Ep is the plasma enrichment of the substrate at steady state. The coefficient of variation for enrichment data for various tracers in individual subjects was between $3 \%$ and $5 \%$; the slope was not different from zero.

Glutamine derived from protein breakdown (BGln) and DGln were calculated as described previously $(13,22)$.

Statistical analysis. The data are reported as mean \pm SD or median (25-75\%) and analyzed using Statistix 7 (Analytic Software, Tallahassee, FL). Cross-over analysis was performed to examine the effect of dose of amino acid on amino acid kinetics and urea Ra within groups. Data between groups was compared using $t$ test and ANOVA. Nonparametric data were analyzed using Wilcoxon Sign rank sum test. Pearson's correlation was performed to examine the relationship between leucine N Ra and DGln. Statistical significance was defined $a$ priori as a $p$ value $<0.05$ (two-tailed).

\section{RESULTS}

Premature infants enrolled in the study were clinically stable and required minimal support (Table 1). The number of babies on caffeine citrate for apneas was not different between groups (AA1.5, 60\%; AA3.0, 60\%; and AA-Ext, 60\%). A higher 
Table 2. Nutrient intake

\begin{tabular}{|c|c|c|c|c|c|c|c|c|c|}
\hline & \multicolumn{3}{|c|}{ AA1.5 $(n=12)$} & \multicolumn{3}{|c|}{ AA3.0 $(n=12)$} & \multicolumn{3}{|c|}{ AA-Ext $(n=5)$} \\
\hline & $\begin{array}{c}\text { Calories } \\
\text { (kcal/kg/d) }\end{array}$ & $\begin{array}{c}\text { Glucose } \\
(\mathrm{mg} / \mathrm{kg} / \mathrm{min})\end{array}$ & $\begin{array}{l}\text { Protein } \\
(\mathrm{g} / \mathrm{kg} / \mathrm{d})\end{array}$ & $\begin{array}{c}\text { Calories } \\
\text { (kcal/kg/d) }\end{array}$ & $\begin{array}{c}\text { Glucose } \\
(\mathrm{mg} / \mathrm{kg} / \mathrm{min})\end{array}$ & $\begin{array}{l}\text { Protein } \\
(\mathrm{g} / \mathrm{kg} / \mathrm{d})\end{array}$ & $\begin{array}{c}\text { Calories } \\
\text { (kcal/kg/d) }\end{array}$ & $\begin{array}{c}\text { Glucose } \\
(\mathrm{mg} / \mathrm{kg} / \mathrm{min})\end{array}$ & $\begin{array}{l}\text { Protein } \\
(\mathrm{g} / \mathrm{kg} / \mathrm{d})\end{array}$ \\
\hline Prestudy & $58 \pm 16$ & $8.1 \pm 2.6$ & $1.7 \pm 0.7$ & $56 \pm 23$ & $7.9 \pm 3.2$ & $1.6 \pm 0.9$ & $61 \pm 10$ & $8.8 \pm 1.3$ & $2.0 \pm 0.4$ \\
\hline $1.5 \mathrm{~g}$ & $76 \pm 13$ & $8.6 \pm 1.7$ & $1.8 \pm 0.3$ & $58 \pm 8$ & $9.2 \pm 1.1$ & $1.6 \pm 0.2$ & $65 \pm 8$ & $7.2 \pm 1.2$ & $1.5 \pm 0.1$ \\
\hline $3.0 \mathrm{~g}$ & $69 \pm 8$ & $10.3 \pm 1.4$ & $3.4 \pm 0.4$ & $76 \pm 9$ & $7.6 \pm 0.8$ & $3.3 \pm 0.3$ & $61 \pm 7$ & $7.4 \pm 0.8$ & $3.1 \pm 0.2$ \\
\hline
\end{tabular}

AA1.5: Parenteral amino acids $1.5 \mathrm{~g} / \mathrm{kg} / \mathrm{d}$ for $20 \mathrm{~h}, 3 \mathrm{~g} / \mathrm{kg} / \mathrm{d}$ for 5 h. AA3.0: Parenteral amino acids $3 \mathrm{~g} / \mathrm{kg} / \mathrm{d}$ for 20 h, $1.5 \mathrm{~g} / \mathrm{kg} / \mathrm{d}$ for 5 h. AA-Ext: Parenteral amino acids $1.5 \mathrm{~g} / \mathrm{kg} / \mathrm{d}$ for $20 \mathrm{~h}, 3 \mathrm{~g} / \mathrm{kg} / \mathrm{d}$ for $20 \mathrm{~h}$.

No significant differences between or within groups.

proportion of infants in AA1.5 group were exposed to antenatal betamethasone (AA1.5, 75\%; AA3.0, 60\%; and AA-Ext, 60\%).

The levels of CRP [AA1.5 $(n=12), 1.90 \pm 1.83$; AA3.0 $(n$ $=12), 2.90 \pm 2.83 \mathrm{mg} / \mathrm{L}], \mathrm{TNF}-\alpha[\mathrm{AA} 1.5(n=4), 3.1 \pm 0.1$; AA3.0 $(n=4), 3.0 \pm 0.1 \mathrm{pg} / \mathrm{mL})$ and cortisol [(AA1.5 $(n=$ $6), 11.6 \pm 9.4 ;$ AA3.0 $(n=6), 10.0 \pm 6.3 \mu \mathrm{g} / \mathrm{dL}]$ were not different between the groups. Metabolic parameters were monitored to evaluate tolerance to higher amino acid load. These parameters were not different when the babies were receiving either $1.5 \mathrm{~g} / \mathrm{kg} / \mathrm{d}$ or $3.0 \mathrm{~g} / \mathrm{kg} / \mathrm{d}$ of parenteral amino acids: $\mathrm{pH}$ (3 $\mathrm{g}: 7.33 \pm 0.04 ; 1.5 \mathrm{~g}: 7.33 \pm 0.01)$, serum bicarbonate $(3 \mathrm{~g}$ : $18.8 \pm 2.7 ; 1.5 \mathrm{~g}: 18.2 \pm 2.3 \mathrm{mM})$, and blood urea nitrogen $(3$ $\mathrm{g}: 16.9 \pm 4.2 ; 1.5 \mathrm{~g}: 20.7 \pm 6.6 \mathrm{mg} / \mathrm{dL})$. The serum ammonia level on $3 \mathrm{~g} / \mathrm{kg} / \mathrm{d}$ was $64 \pm 37 \mu \mathrm{M} / \mathrm{L}$. Provision of higher amounts of amino acids had no impact on blood glucose $(3 \mathrm{~g}$ : $83 \pm 19 ; 1.5 \mathrm{~g}: 92 \pm 28 \mathrm{mg} / \mathrm{dL})$ or plasma insulin concentration $[3 \mathrm{~g}: 12.8 \pm 6.6,(n=15) ; 1.5 \mathrm{~g}: 12.6 \pm 6.6(n=15)$ $\mu \mathrm{U} / \mathrm{mL}]$.

Plasma amino acids. An increase in parenteral amino acids to $3 \mathrm{~g} / \mathrm{kg} / \mathrm{d}$ for $5 \mathrm{~h}$ resulted in a significant increase in the concentration of glutamine, branched-chain (leucine, isoleu- cine, and valine), and gluconeogenic (serine, threonine, glycine, and alanine) amino acids (Table 3). Prolonged infusion (20 h) of high dose of amino acids (AA-Ext) was associated with a greater rise in the concentration of glutamine as well as other amino acids. In contrast, lowering amino acids to 1.5 $\mathrm{g} / \mathrm{kg} / \mathrm{d}$ for $5 \mathrm{~h}$ (AA3.0) did not cause any change in the concentration of glutamine, whereas the levels of essential and gluconeogenic amino acids declined (Table 3).

Phenylalanine kinetics. The total phenylalanine $\mathrm{Ra}$ in the whole study population $(n=29)$ was $82.9 \pm 14.3 \mu \mathrm{mol} / \mathrm{kg} / \mathrm{h}$ when babies were receiving parenteral nutrition at $1.5 \mathrm{~g} / \mathrm{kg} / \mathrm{d}$, and $100.3 \pm 13.7 \mu \mathrm{mol} / \mathrm{kg} / \mathrm{h}$ when the amino acid dose was 3.0 $\mathrm{g} / \mathrm{kg} / \mathrm{d}$ (Table 4$)$. The corresponding Ra of endogenous phenylalanine was $65.1 \pm 14.3$ and $64.5 \pm 13.7 \mu \mathrm{mol} / \mathrm{kg} / \mathrm{h}(\mathrm{NS})$. Evaluation of data of each group individually showed that endogenous phenylalanine $\mathrm{Ra}$ decreased significantly in group AA1.5 $(p<0.001)$ when the amino acid infusion was increased from 1.5 to $3.0 \mathrm{~g} / \mathrm{kg} / \mathrm{d}$ for $5 \mathrm{~h}$. However, there was no significant change in endogenous phenylalanine $\mathrm{Ra}$ in group AA3.0 or group AA-Ext with change in amino acid load (Table 5).

Table 3. Plasma concentration of amino acids ( $\mathrm{mol} / \mathrm{L})$

\begin{tabular}{|c|c|c|c|c|c|c|}
\hline & \multicolumn{2}{|c|}{ AA1.5 $(n=12)$} & \multicolumn{2}{|c|}{ AA3.0 $(n=12)$} & \multicolumn{2}{|c|}{ AA-Ext $(n=5)$} \\
\hline Aspartic acid & $8 \pm 2$ & $12 \pm 3$ & $7 \pm 2$ & $11 \pm 5$ & $11 \pm 2$ & $15 \pm 3^{*}$ \\
\hline Asparagine & $13 \pm 5$ & $12 \pm 3$ & $22 \pm 9$ & $16 \pm 6$ & $16 \pm 5$ & $17 \pm 5$ \\
\hline Serine & $114 \pm 35$ & $163 \pm 47 * *$ & $146 \pm 39$ & $164 \pm 44^{* *}$ & $133 \pm 40$ & $239 \pm 70 *$ \\
\hline Histidine & $93 \pm 30$ & $120 \pm 41^{* *}$ & $96 \pm 23$ & $109 \pm 24$ & $96 \pm 25$ & $164 \pm 38^{*}$ \\
\hline Threonine & $129 \pm 46$ & $192 \pm 62 * *$ & $184 \pm 68$ & $209 \pm 73 * *$ & $127 \pm 69$ & $291 \pm 124$ \\
\hline Citrulline & $19 \pm 7$ & $24 \pm 7 * *$ & $25 \pm 12$ & $28 \pm 9 *$ & $15 \pm 7$ & $20 \pm 1$ \\
\hline Arginine & $79 \pm 45$ & $149 \pm 71 * *$ & $112 \pm 56$ & $175 \pm 90^{* *}$ & $90 \pm 34$ & $253 \pm 89 *$ \\
\hline Alanine & $90 \pm 40$ & $129 \pm 50 * *$ & $115 \pm 49$ & $145 \pm 61^{*}$ & $84 \pm 35$ & $197 \pm 93 *$ \\
\hline Taurine & $42 \pm 28$ & $54 \pm 40^{*}$ & $66 \pm 33$ & $62 \pm 36$ & $27 \pm 19$ & $55 \pm 5$ \\
\hline Tyrosine & $69 \pm 32$ & $90 \pm 38$ & $105 \pm 72$ & $104 \pm 57$ & $77 \pm 35$ & $102 \pm 20$ \\
\hline Isoleucine & $45 \pm 11$ & $86 \pm 15 * *$ & $49 \pm 12$ & $79 \pm 20 * *$ & $47 \pm 10$ & $99 \pm 12 * *$ \\
\hline Leucine & $97 \pm 24$ & $174 \pm 34 * *$ & $110 \pm 29$ & $165 \pm 44^{* *}$ & $102 \pm 17$ & $198 \pm 30^{* *}$ \\
\hline Ornithine & $57 \pm 29$ & $135 \pm 58 * *$ & $103 \pm 60$ & $159 \pm 76^{* *}$ & $61 \pm 13$ & $211 \pm 39^{* *}$ \\
\hline Lysine & $111 \pm 55$ & $198 \pm 72 * *$ & $158 \pm 61$ & $221 \pm 86^{* *}$ & $101 \pm 28$ & $240 \pm 51 * *$ \\
\hline
\end{tabular}

$* p<0.05 ; * * p<0.01 ; 1.5 \mathrm{~g}$ vs $3.0 \mathrm{~g}$, two-tailed paired analysis.

AA1.5: Parenteral amino acids $1.5 \mathrm{~g} / \mathrm{kg} / \mathrm{d}$ for $20 \mathrm{~h}, 3 \mathrm{~g} / \mathrm{kg} / \mathrm{d}$ for $5 \mathrm{~h}$. AA3.0: Parenteral amino acids $3 \mathrm{~g} / \mathrm{kg} / \mathrm{d}$ for 20 h, $1.5 \mathrm{~g} / \mathrm{kg} / \mathrm{d}$ for 5 h. AA-Ext: Parenteral amino acids $1.5 \mathrm{~g} / \mathrm{kg} / \mathrm{d}$ for $20 \mathrm{~h}, 3 \mathrm{~g} / \mathrm{kg} / \mathrm{d}$ for $20 \mathrm{~h}$. 
Table 4. Phenylalanine and leucine kinetics

\begin{tabular}{|c|c|c|c|c|c|c|}
\hline & \multicolumn{2}{|c|}{ AA1.5 $(n=12)$} & \multicolumn{2}{|c|}{ AA $3.0(n=12)$} & \multicolumn{2}{|c|}{ AA-Ext $(n=5)$} \\
\hline & $1.5 \mathrm{~g}(20 \mathrm{~h})$ & $3.0 \mathrm{~g}(5 \mathrm{~h})$ & $3.0 \mathrm{~g}(20 \mathrm{~h})$ & $1.5 \mathrm{~g}(5 \mathrm{~h})$ & $1.5 \mathrm{~g}(20 \mathrm{~h})$ & $3.0 \mathrm{~g}(20 \mathrm{~h})$ \\
\hline \multicolumn{7}{|c|}{ Phenylalanine $\mathrm{Ra}^{*}$} \\
\hline Total & $90 \pm 16$ & $101 \pm 15^{* *}$ & $97 \pm 13^{* *}$ & $79 \pm 13$ & $79 \pm 16$ & $110 \pm 16^{* *}$ \\
\hline Endogenous & $71 \pm 16$ & $64 \pm 14 * *$ & $62 \pm 13$ & $60 \pm 11$ & $61 \pm 17$ & $74 \pm 16$ \\
\hline Leucine $\mathrm{N} \mathrm{Ra*}$ & $419 \pm 39$ & $573 \pm 77 * *$ & $577 \pm 117 * *$ & $416 \pm 97$ & $398 \pm 57$ & $657 \pm 92 * *$ \\
\hline
\end{tabular}

$* \mu \mathrm{mol} / \mathrm{kg} / \mathrm{h} ; * * p<0.001 ; 1.5 \mathrm{~g}$ vs $3.0 \mathrm{~g}$, two-tailed paired analysis.

AA1.5: Parenteral amino acids $1.5 \mathrm{~g} / \mathrm{kg} / \mathrm{d}$ for $20 \mathrm{~h}, 3 \mathrm{~g} / \mathrm{kg} / \mathrm{d}$ for $5 \mathrm{~h}$. AA3.0: Parenteral amino acids $3 \mathrm{~g} / \mathrm{kg} / \mathrm{d}$ for $20 \mathrm{~h}, 1.5 \mathrm{~g} / \mathrm{kg} / \mathrm{d}$ for 5 h. AA-Ext: Parenteral amino acids $1.5 \mathrm{~g} / \mathrm{kg} / \mathrm{d}$ for $20 \mathrm{~h}, 3 \mathrm{~g} / \mathrm{kg} / \mathrm{d}$ for $20 \mathrm{~h}$.

Phenylalanine $\mathrm{Ra}$ (endogenous) calculated by subtracting phenylalanine in the parenteral nutrition from total phenylalanine $\mathrm{Ra}(3 \mathrm{~g}=36 \mathrm{~mol} / \mathrm{kg} / \mathrm{h} ; 1.5 \mathrm{~g}=$ $18 \mathrm{~mol} / \mathrm{kg} / \mathrm{h})$

Table 5. Glutamine and Urea N Kinetics

\begin{tabular}{|c|c|c|c|c|c|c|}
\hline & \multicolumn{2}{|c|}{ AA1.5 $(n=12)$} & \multicolumn{2}{|c|}{ AA3.0 $(n=12)$} & \multicolumn{2}{|c|}{ AA-Ext $(n=5)$} \\
\hline \multicolumn{7}{|c|}{ Glutamine $\mathrm{Ra}^{*}$} \\
\hline B Gln & $77 \pm 18$ & $69 \pm 16$ & $66 \pm 15$ & $66 \pm 14$ & $65 \pm 17$ & $79 \pm 17$ \\
\hline D Gln & $378 \pm 78$ & $386 \pm 67$ & $479 \pm 100^{* *}$ & $372 \pm 77$ & $411 \pm 47$ & $522 \pm 53^{* *}$ \\
\hline Urea Ra* & $523 \pm 153$ & $480 \pm 135^{* *}$ & $533 \pm 165^{* *}$ & $462 \pm 141$ & $364 \pm 107$ & $560 \pm 74 * *$ \\
\hline
\end{tabular}

$* \mu \mathrm{mol} / \mathrm{kg} / \mathrm{h} ; * * p<0.01 ; 1.5 \mathrm{~g}$ vs $3.0 \mathrm{~g}$, two-tailed paired analysis.

AA1.5: Parenteral amino acids $1.5 \mathrm{~g} / \mathrm{kg} / \mathrm{d}$ for $20 \mathrm{~h}, 3 \mathrm{~g} / \mathrm{kg} / \mathrm{d}$ for $5 \mathrm{~h}$. AA3.0: Parenteral amino acids $3 \mathrm{~g} / \mathrm{kg} / \mathrm{d}$ for $20 \mathrm{~h}, 1.5 \mathrm{~g} / \mathrm{kg} / \mathrm{d}$ for 5 h. AA-Ext: Parenteral amino acids $1.5 \mathrm{~g} / \mathrm{kg} / \mathrm{d}$ for $20 \mathrm{~h}, 3 \mathrm{~g} / \mathrm{kg} / \mathrm{d}$ for $20 \mathrm{~h}$. B Gln (fraction from proteolysis = phenylalanine (endogenous) * 1.07. D Gln (total Glutamine Ra - B Gln).

Leucine $\boldsymbol{N}$ Ra. Leucine nitrogen $\mathrm{Ra}$ was $421.1 \pm 63.8$ $\mu \mathrm{mol} / \mathrm{kg} / \mathrm{h}$ when the rate of amino acid infusion was 1.5 $\mathrm{g} / \mathrm{kg} / \mathrm{d}$. Higher rate of amino acid administration resulted in a significant $(p<0.0001)$ increase in leucine $\mathrm{N} \mathrm{Ra}$ in the three groups individually and in the entire population.

Glutamine and urea kinetics. Glutamine $\mathrm{Ra}$ was $442 \pm 71$ $\mu \mathrm{mol} / \mathrm{kg} / \mathrm{h}$ at an amino acid dose of $1.5 \mathrm{~g} / \mathrm{kg} / \mathrm{d}$, and increased to $505 \pm 92 \mu \mathrm{mol} / \mathrm{kg} / \mathrm{h}$ at $3.0 \mathrm{~g} / \mathrm{kg} / \mathrm{d}(n=29, p<0.01)$. The higher glutamine Ra was associated with a higher rate of urea synthesis, as measured by $\left[{ }^{15} \mathrm{~N}_{2}\right]$ urea tracer dilution $(p<0.05)$. Evaluation of individual group data showed that glutamine Ra was higher in AA3.0 and AA-Ext when amino acids were infused at the higher dose $(p<0.01)$. Inasmuch as there was no change in phenylalanine $\mathrm{Ra}$ or the whole-body rate of protein breakdown, the higher glutamine $\mathrm{Ra}$ at $3 \mathrm{~g}$ amino acids $/ \mathrm{kg} / \mathrm{d}$ was entirely due to a higher rate of DGln ( $p=$ 0.001 ). The increased rate of DGln was associated with an increased rate of synthesis of urea in groups AA3.0 and AA-Ext.

In contrast, a high rate of amino acid infusion for $5 \mathrm{~h}$ did not result in any significant change in glutamine Ra and DGln in group AA1.5; however, there was a slight decrease in BGln. Amino acid infusion at $3 \mathrm{~g} / \mathrm{kg} / \mathrm{d}$ for $5 \mathrm{~h}$ was associated with a significant decrease in the rate of urea synthesis in this group $(p<0.01)$.

The ${ }^{15} \mathrm{~N}$ enrichment of plasma glutamate was $0.43 \%$, whereas ${ }^{15} \mathrm{~N}$ enrichment of glutamine was $6-7 \%$. The appearance of ${ }^{15} \mathrm{~N}$ from the infused leucine contributed to approximately $7 \%$ to the measured glutamine enrichment and consequently resulted in a small underestimation of Ra glutamine in all the groups.

Correlations: There was a significant correlation between leucine $\mathrm{N}$ Ra and the rate of DGln in groups 2 and $3\left(r^{2}=\right.$
$0.48, p<0.01)$. Such a correlation was not seen among babies in group AA1.5.

\section{DISCUSSION}

We have examined the effect of two doses of parenteral amino acids on whole-body nitrogen metabolism in a clinically stable population of VLBW infants. Even though the babies were carefully randomized using sealed envelopes, distinct differences in results were observed in group AA1.5 (i.e. initially $1.5 \mathrm{~g}$ amino acid and then increased to $3.0 \mathrm{~g}$ amino acid) when compared with groups AA3.0 and AA-Ext. Higher amino acid load $(3 \mathrm{~g} / \mathrm{kg} / \mathrm{d})$ for $5 \mathrm{~h}$ caused an increase in leucine $\mathrm{N}$ turnover but no change in glutamine Ra. Of interest, phenylalanine Ra and urea synthesis decreased when the dose of amino acid infusion was increased. In contrast, when amino acid load was decreased from 3.0 to $1.5 \mathrm{~g}$ in group AA3.0, there was a corresponding decrease in Ra of glutamine, urea and leucine $\mathrm{N}$, whereas there was no change in Ra of phenylalanine. Finally, babies in group AA-Ext showed an increase in $\mathrm{Ra}$ of glutamine, urea and leucine $\mathrm{N}$ with prolonged infusion $(20 \mathrm{~h})$ of higher dose of parenteral amino acids. There was no impact on phenylalanine kinetics. The data of group AA1.5 are surprising and of interest, and will be discussed separately. Although babies in group AA-Ext were all females, gender had no effect on the measured kinetic data in the study. Other than the sequence of amino acid infusion, there were no discernable differences in the three groups.

The glutamine $\mathrm{Ra}$ was higher when clinically stable (unstressed) preterm infants in groups AA3.0 and AA-Ext were given a higher load of amino acids. We have observed that provision of a higher dose of amino acid $(3.0 \mathrm{~g} / \mathrm{kg} / \mathrm{d})$ to acutely ill (stressed) infants also resulted in a higher rate of DGln 
(unpublished observation). Glutamine constitutes the major cataplerotic outflow of carbon from the TCA cycle. Because cataplerosis from TCA cycle is balanced with the inflow of carbon precursors (anaplerosis) (10), a higher glutamine flux would be expected in response to increased parenteral amino acid infusion. Lundholm and colleagues (23), in normal healthy adults, also showed an increased DGln across the leg in response to infusion of a balanced amino acid solution. A similar observation was made by Abumrad and colleagues (24) across forearm skeletal muscle during intravenous amino acid infusion. Significantly, in both these studies in healthy adults, there was a net reversal of the $\alpha$-amino nitrogen release from the skeletal muscle, whereas glutamine (and alanine) release persisted throughout the amino acid infusion. Since the net amino acid release had been suppressed or reversed, the persistent glutamine release in these studies was the consequence of DGln from the infused amino acids. A similar inference, i.e. increased rate of glutamine synthesis, can be drawn from the data in AA3.0 and AA-Ext of the present study, since the rate of proteolysis (i.e. phenylalanine $\mathrm{Ra}$ ) did not change in response to higher rate of amino acid infusion. That exogenously infused amino acids were the precursor carbon and nitrogen for glutamine and alanine is also supported by the studies of Chang and Goldberg (25) and of Garber et al. (26) in isolated perfused muscle, where provision of exogenous amino acids resulted in an increased glutamine efflux from the muscle. As anticipated, higher rate of DGln was associated with a higher rate of branched chain amino acid transamination, resulting in a higher rate of leucine $\mathrm{N} \mathrm{Ra}$. Although the above suggests skeletal muscle to be the major site for glutamine synthesis during amino acid infusion, it is not likely to be the predominant contributor. Studies in human adults show that only $25-30 \%$ of infused amino acid nitrogen is taken up by the skeletal muscle and $70 \%$ is removed by the splanchnic compartment $(23,27,28)$. Thus, it is likely that the observed increase in Ra of glutamine in response to increased amino acid infusion is contributed by both the skeletal muscle as well as by the splanchnic organs.

With the higher nitrogen load, the rate of urea synthesis was higher in groups AA3.0 and AA-Ext, suggesting an increase in rate, irreversible nitrogen loss, of oxidation of protein. The increase in urea synthesis was not associated with a greater fractional contribution of glutamine $\mathrm{N}$ to urea, suggesting that peripheral glutamine is not the major contributor of urea $\mathrm{N}$. This was in the presence of a higher appearance of glutamine. As indicated above, data from studies in healthy adults have shown the splanchnic compartment to be the major site of disposal of amino acids. Therefore, the higher synthesis of urea with higher amino acid infusion is probably the consequence of a higher rate of metabolism of amino acids in the splanchnic compartment. Higher splanchnic uptake and metabolism of amino acids would support the hepatic gluconeogenesis and hepatic synthesis of acute phase and hepatic and enteral proteins.

Although an increase in glutamine synthesis and higher plasma levels of glutamine were associated with higher rate of amino acid infusion, there was no effect on whole-body phenylalanine Ra or protein breakdown. These data are in contrast to the studies showing a decrease in proteolysis in humans and animals, when glutamine levels are increased by exogenous infusion of glutamine with TPN (29). However, in these studies glutamine synthesis $(\mathrm{Ra})$ was also decreased in response to glutamine infusion. Thus, the suppression of proteolysis or increased protein synthesis may require both higher glutamine levels in the intracellular compartment as well as suppression of glutamine synthesis, which was not the case in groups AA3.0 and AA-Ext.

Provision of a higher amount $(1.5-3.0 \mathrm{~g} / \mathrm{kg} / \mathrm{d})$ of parenteral amino acid for $5 \mathrm{~h}$ in group AA1.5 resulted in a decrease in phenylalanine $\mathrm{Ra}$ and urea synthesis, suggesting a decrease in the rate of breakdown and oxidation of protein. Suppression of proteolysis was associated with no change in the rate of appearance of glutamine and an increase in leucine $\mathrm{N} \mathrm{Ra}$. Parenteral amino acid infusions of short duration have been shown to result in a lower rate of proteolysis in both adults and healthy newborn infants (30-37). A decrease in the rate of protein breakdown (phenylalanine Ra) in the presence of an increase in amino acid infusion suggests an increase in the rate of protein synthesis. However, when the higher rate of amino acid infusion was prolonged for $24 \mathrm{~h}$ (groups AA3.0 and AA-Ext), these acute responses in whole-body protein and glutamine kinetics were not sustained. These observations suggest that the response to amino acid infusion were transient. To our knowledge, such a temporal effect of amino acid infusion on whole-body rate of proteolysis has not been examined previously in human or animal studies. Previous studies in human adults and newborn infants have only examined the responses during 3-6 h of amino acid infusions. These acute responses have been attributed to increased substrate availability and independent of plasma insulin and IGF (38). Although the data from our study cannot identify the mechanism of the transient response, we speculate that the adaptation to the higher amino acid concentrations may have resulted in inhibition of the amino acid transporter systems. Studies in vitro have shown that mammalian cells in culture rapidly adapt to amino acid availability by altering the transcription and translation of the genes of amino acid transporters $(39,40)$. In the absence of other mediators of protein synthesis and breakdown, or of amino acid transporter, the observed effects of amino acid infusion of short duration would disappear when the infusions are given for a longer time.

In summary, the data from the present study show that provision of higher amount of amino acids in VLBW babies appear to have a transient impact on whole-body rate of protein breakdown and urea synthesis, and that such an effect disappears when the amino acids are infused for a prolonged period.

Acknowledgments. The authors thank the nursing staff of the General Clinical Research Center for their help with these studies, and Dr. Saeid Amini for statistical analysis. We also thank Ms. Joyce Nolan for secretarial help.

\section{REFERENCES}

1. Smith RJ 1990 Glutamine metabolism and its physiologic importance. J Parenter Enteral Nutr 14: 40S-44S

2. Yeh SL, Lai YN, Shang HF, Lin MT, Chen WJ 2004 Effects of glutamine supplementation on innate immune response in rats with gut-derived sepsis. Br J Nutr 91:423-429 
3. Li N, Liboni K, Fang MZ, Samuelson D, Lewis P, Patel R, Neu J 2004 Glutamine decreases lipopolysaccharide-induced intestinal inflammation in infant rats. Am J Physiol Gastrointest Liver Physiol 286:G914-G921

4. Newsholme P 2001 Why is L-glutamine metabolism important to cells of the immune system in health, postinjury, surgery or infection? J Nutr 131: 2515S-2522S

5. Ziegler TR, Young LS, Benfell K, Scheltinga M, Hortos K, Bye R, Morrow FD, Jacobs DO, Smith RJ, Antin JH et al 1992 Clinical and metabolic efficacy of glutamine-supplemented parenteral nutrition after bone marrow transplantation. A randomized, double-blind, controlled study. Ann Intern Med 116:821-828

6. Melis GC, ter Wengel N, Boelens PG, van Leeuwen PA 2004 Glutamine: recen developments in research on the clinical significance of glutamine. Curr Opin Clin Nutr Metab Care 7:59-70

7. Neu J, DeMarco V, Weiss M 1999 Glutamine supplementation in low-birth-weight infants: mechanisms of action. J Parenter Enteral Nutr 23:S49-S51

8. des Robert C, Le Bacquer O, Piloquet H, Roze JC, Darmaun D 2002 Acute effects of intravenous glutamine supplementation on protein metabolism in very low birth weight infants: a stable isotope study. Pediatr Res 51:87-93

9. Lacey JM, Crouch JB, Benfell K, Ringer SA, Wilmore CK, Maguire D, Wilmore DW 1996 The effects of glutamine-supplemented parenteral nutrition in premature infants. J Parenter Enteral Nutr 20:74-80

10. Owen OE, Kalhan SC, Hanson RW 2002 The key role of anaplerosis and cataplerosis for citric acid cycle function. J Biol Chem 277:30409-30412

11. Wernerman J, Hammarkvist F, Ali MR, Vinnars E 1989 Glutamine and ornithine alpha-ketoglutarate but not branched-chain amino acids reduce the loss of muscle glutamine after surgical trauma. Metabolism 38:63-66

12. Vinnars E, Hammarqvist F, von der Decken A, Wernerman J 1990 Role of glutamine and its analogs in posttraumatic muscle protein and amino acid metabolism. J Parenter Enteral Nutr 14: 125S-129S

13. Parimi PS, Devapatla S, Gruca L, O’Brien AM, Hanson RW, Kalhan SC 2002 Glutamine and leucine nitrogen kinetics and their relation to urea nitrogen in newborn infants. Am J Physiol Endocrinol Metab 282:E618-E625

14. Kalhan SC, Denne SC, Patel DM, Nuamah IF, Savin SM 1994 Leucine kinetics during a brief fast in diabetes in pregnancy. Metabolism 43:378-384

15. Turnell DC, Cooper JD 1982 Rapid assay for amino acids in serum or urine by pre-column derivatization and reversed-phase liquid chromatography. Clin Chem 28:527-531

16. Denne SC, Kalhan SC 1987 Leucine metabolism in human newborns. Am J Physiol 253:E608-E615

17. Tserng KY, Kalhan SC 1982 Gas chromatography/mass spectrometric determination of $\left[{ }^{15}-\mathrm{N}\right]$ urea in plasma and application to urea metabolism study. Anal Chem 54:489-491

18. Parimi PS, Devapatla S, Gruca L, O'Brien AM, Hanson RW, Kalhan SC 2002 Glutamine and leucine nitrogen kinetics and their relation to urea nitrogen in newborn infants. Am J Physiol Endocrinol Metab 282:E618-E625

19. Parimi PS, Devapatla S, Gruca LL, Amini SB, Hanson RW, Kalhan SC 2004 Effect of enteral glutamine or glycine on whole-body nitrogen kinetics in very-low-birthweight infants. Am J Clin Nutr 79:402-409

20. Adams RF 1974 Determination of amino acid profiles in biological samples by gas chromatography. J Chromatogr Sci 95:189-212

21. Haisch M, Fukagawa NK, Matthews DE 2000 Oxidation of glutamine by the splanchnic bed in humans. Am J Physiol Endocrinol Metab 278:E593-E602

22. Kuhn KS, Schuhmann K, Stehle P, Darmaun D, Furst P 1999 Determination of glutamine in muscle protein facilitates accurate assessment of proteolysis and de novo synthesis-derived endogenous glutamine production. Am J Clin Nutr 70:484-489
23. Lundholm K, Bennegard K, Zachrisson H, Lundgren F, Eden E, Moller-Loswick AC 1987 Transport kinetics of amino acids across the resting human leg. J Clin Invest 80:763-771

24. Abumrad NN, Rabin D, Wise KL, Lacy WW 1982 The disposal of an intravenously administered amino acid load across the human forearm. Metabolism 31:463-470

25. Chang TW, Goldberg AL 1978 The metabolic fates of amino acids and the formation of glutamine in skeletal muscle. J Biol Chem 253:3685-3693

26. Garber AJ, Karl IE, Kipnis DM 1976 Alanine and glutamine synthesis and release from skeletal muscle. II. The precursor role of amino acids in alanine and glutamine synthesis. J Biol Chem 251:836-843

27. Gelfand RA, Glickman MG, Jacob R, Sherwin RS, DeFronzo RA 1986 Removal of infused amino acids by splanchnic and leg tissues in humans. Am J Physiol 250:E407-E413

28. Ferrannini E, DeFronzo RA, Gusberg R, Tepler J, Jacob R, Aaron M, Smith D, Barrett EJ 1988 Splanchnic amino acid and glucose metabolism during amino acid infusion in dogs. Diabetes 37:237-245

29. Kalhan SC, Parimi PS, Gruca LL, Hanson RW 2005 Glutamine supplement with parenteral nutrition decreases whole body proteolysis in low birth weight infants. J Pediatr 146:642-647

30. Pacy PJ, Garrow JS, Ford GC, Merritt H, Halliday D 1988 Influence of amino acid administration on whole-body leucine kinetics and resting metabolic rate in postabsorptive normal subjects. Clin Sci 75:225-231

31. Bennet WM, Connacher AA, Scrimgeour CM, Smith K, Rennie MJ 1989 Increase in anterior tibialis muscle protein synthesis in healthy man during mixed amino acid infusion: studies of incorporation of $\left[1{ }^{13} \mathrm{C}\right]$ leucine. Clin Sci 76:447-454

32. Bennet WM, Connacher AA, Scrimgeour CM, Rennie MJ 1990 The effect of amino acid infusion on leg protein turnover assessed by L- $\left[{ }^{15} \mathrm{~N}\right]$ phenylalanine and L- $[1-$ ${ }^{13}$ C]leucine exchange. Eur J Clin Invest 20:41-50

33. Ferrannini E, DeFronzo RA, Gusberg R, Tepler J, Jacob R, Aaron M, Smith D, Barrett EJ 1988 Splanchnic amino acid and glucose metabolism during amino acid infusion in dogs. Diabetes 37:237-245

34. Ferrannini E, Bevilacqua S, Lanzone L, Bonadonna R, Brandi L, Oleggini M, Boni C, Buzzigoli G, Ciociaro D, Luzi L, DeFronzo RA 1988 Metabolic interactions of amino acids and glucose in healthy humans. Diabetes Nutr Metab 3:175-186

35. Volpi E, Ferrando AA, Yeckel CW, Tipton KD, Wolfe RR 1998 Exogenous amino acids stimulate net muscle protein synthesis in the elderly. J Clin Invest 101:2000 2007

36. Biolo G, Tipton KD, Klein S, Wolfe RR 1997 An abundant supply of amino acids enhances the metabolic effect of exercise on muscle protein. Am J Physiol 273:E122_ E129

37. Poindexter BB, Karn CA, Ahlrichs JA, Wang J, Leitch CA, Liechty EA, Denne SC 1997 Amino acids suppress proteolysis independent of insulin throughout the neonatal period. Am J Physiol 272:E592-E599

38. Svanberg E, Möller-Loswick AC, Matthews DE, Körner U, Andersson M, Lundholm K 1996 Effects of amino acids on synthesis and degradation of skeletal muscle proteins in humans. Am J Physiol 271:E718-E824

39. Hyatt SL, Aulak KS, Malandro M, Kilberg MS, Hatzoglou M 1997 Adaptive regulation of the cationic amino acid transporter-1 (Cat-1) in Fao cells. J Biol Chem 272:19951-19957

40. Bracy DS, Handlogten ME, Barber EF, Han HP, Kilberg MS 1986 Cis-inhibition, trans-inhibition, and repression of hepatic amino acid transport mediated by System A. Substrate specificity and other properties. J Biol Chem 261:1514-1520 